\title{
Primary Breast Tuberculosis Mimicking Carcinomatous Mastitis: A Case Report
}

\section{Zo Irène Raivoherivony ${ }^{1}$, Lalaina Nomenjanahary ${ }^{1}$, Fenohery Nalisoa Rakotondrainibe ${ }^{2}$, Nantenaina Soa Randrianjafisamindrakotroka ${ }^{3}$}

\author{
${ }^{1}$ Department of Pathology, Joseph Ravoahangy Andrianavalona University Hospital, Antananarivo, Madagascar \\ ${ }^{2}$ Department of Pathology, Anosiala University Hospital, Antananarivo, Madagascar \\ ${ }^{3}$ Department of Pathology, Medical School of Antananarivo, Antananarivo, Madagascar \\ Email: *ireneraivoherivony@gmail.com, nlalaina@yahoo.fr, fenoherynalisoa@gmail.com, randriante@gmail.com
}

How to cite this paper: Raivoherivony, Z.I., Nomenjanahary, L., Rakotondrainibe, F.N. and Randrianjafisamindrakotroka, N.S. (2021) Primary Breast Tuberculosis Mimicking Carcinomatous Mastitis: A Case Report. Open Journal of Pathology, 11, 79-83.

https://doi.org/10.4236/ojpathology.2021.1 $\underline{13007}$

Received: May 8, 2021

Accepted: July 9, 2021

Published: July 12, 2021

Copyright $\odot 2021$ by author(s) and Scientific Research Publishing Inc. This work is licensed under the Creative Commons Attribution International License (CC BY 4.0). http://creativecommons.org/licenses/by/4.0/

\begin{abstract}
The breast is a rare localization of extra-pulmonary tuberculosis, even in highly endemic countries. It is most often primitive. The clinical and radiological features are sometimes misleading. It poses diagnostic problems especially with cancer. We report a case of breast tuberculosis having clinical and radiological presentations as a breast carcinoma. Through this observation and a review of the literature, we provide an update on the epidemiological characteristics and the means of diagnosis of this lesion. It was a 52-year-old woman with inflammatory lump of the left breast, adherent to the skin. Ultrasonography and mammography revealed a homogeneous, poorly demarcated nodule of approximately $4 \mathrm{~cm}$ of diameter, classified ACR4. Surgical excision was performed. The histological diagnosis was breast tuberculosis. The diagnosis of tuberculous mastitis is made on bacteriological and pathological examinations. Histological examination helps for diagnostic confirmation while excluding a malignant lesion of the breast.
\end{abstract}

\section{Keywords}

Mastitis, Breast Disease, Extra-Pulmonary Tuberculosis

\section{Introduction}

Tuberculosis is an infectious disease caused by tissue infiltration of Mycobacterium tuberculosis or Koch's Bacillus. Extra-pulmonary localizations concern $20 \%$ to $40 \%$ of cases depending on the series. Tuberculous mastitis is rare and represents $0.06 \%$ to $0.1 \%$ of all tuberculosis cases [1], and less than $0.1 \%$ of all mammary pathologies [2]. Due to its rarity and variable clinical presentations, 
breast tuberculosis can be confused clinically and radiologically with other breast diseases [3]. We report a case of breast tuberculosis mimicking breast carcinoma. Through the analysis of this case and the literature review, we focus on the epidemiological characteristics and the role of histological examination for the diagnosis.

\section{Case Report}

It was a 52-year-old woman, multiparous, with no notable history, including tuberculosis. She complained for painful lump on the upper outer quadrant of the left breast, which had appeared for a month. Clinical examination revealed an irregular lump, fixed to the skin with inflammation of overlying skin. The contralateral breast was normal. The lymph node areas were free. Mammography and mammary ultrasonography found an opacity of the upper outer quadrant, ill-defined, $4 \mathrm{~cm}$ in diameter. It was classified as ACR4 according to the American College of Radiology classification. Carcinomatous mastitis was suspected and the patient underwent surgical excision.

On gross examination, the specimen was yellowish and firm, measuring $5 \times 4$ $\times 4 \mathrm{~cm}$. The sectioned surface was consisting of a yellowish-white area of fibrous, ill-defined, $4 \mathrm{~cm}$ of diameter. On histological examination, there was an inflammatory granulomatous reaction on the breast tissue, composed of numerous epithelioid granulomas often centered by caseous necrosis, with multinucleated giant cells Langhans type (Figure 1). The diagnosis was breast tuberculosis.

The patient was put on anti-tubercular drugs treatment (Rifampicin $600 \mathrm{mg}$, Isoniazid $300 \mathrm{mg}$, Pyrazinamide $1500 \mathrm{mg}$, Ethambitol $1000 \mathrm{mg}$, per day) for 2 months and Rifampicine with Isoziazid therapy for 4 months. In the follow-up period, the physical examination was found to be normal after 6 months.

\section{Discussion}

Breast tuberculosis is rare because the breast tissue appears to be more resistant to infection and less probable location for the survival and multiplication of

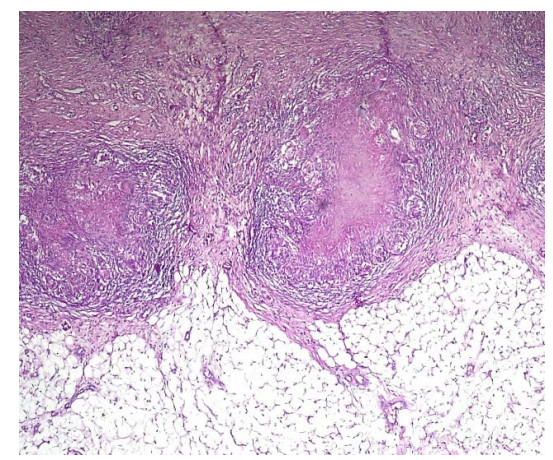

(a)

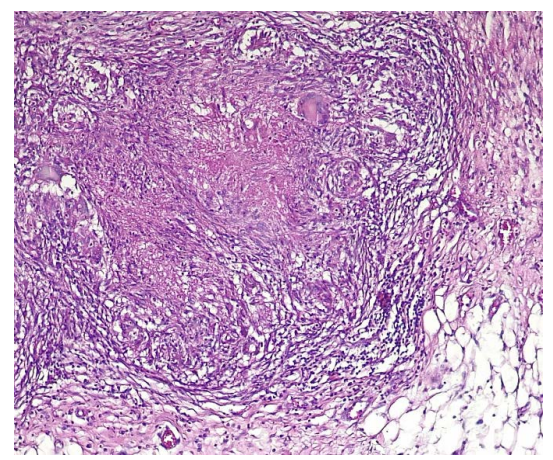

(b)

Figure 1. Breast tuberculosis. Epithelioid granulomas with multinucleated giant cells Langhans type, caseous necrosis. HE $\times 40$ (a) $\times 100$ (b). Source: Department of pathology at JRA hospital. 
Mycobacterium tuberculosis [3] [4] [5]. The incidence of breast tuberculosis ranges from $0.10 \%$ to $0.52 \%$ worldwide, even in endemic countries, such as Africa [4]. The risk factors reported in the literature are multiparty, breastfeeding, breast trauma and chronic mastitis [3]. Tuberculous mastitis affects mainly women of reproductive age [6], usually ( $83 \%$ to $95 \%$ of cases), between 20 and 40 years [7]. For Mehta G et al. [8], 49.2\% of women were under 30 years old. This pathology affects $70 \%$ to $81 \%$ of women between 20 and 40 years old in the study by Shinde S.R et al. [9], and 55\% for H. Zekri et al. [3]. Our patient was 52 years old, which was similar than the study of Hawilo A. et al. [10] that have found a peak in frequency of the disease in postmenopausal patients over 50 years (62.5\%). Multiparty and breastfeeding were the risk factors for our patient.

The clinical presentation of breast tuberculosis is not specific, extremely variable. Symptoms can mimic a large number of benign or malignant lesions of the breast [4] [11] [12].

In their series, Hawilo A. et al. [10] noted an inflammatory or ulcerated lesion of the nipple suggesting a malignant tumor in four cases, a collected abscess in two cases and a well-limited asymptomatic nodule with benign appearance in two cases. For Emma McGuire et al. [13], the most frequent clinical presentation was breast lump ( $87 \%$ of cases) on the upper outer quadrant in $88 \%$ of cases. This preponderance may be due to retrograde lymphatic dissemination of bacilli from the axillary lymph nodes to the adjacent upper outer breast tissue [13]. Our case was similar to this clinical appearance but it was associated with inflammation of overlying skin.

Regarding laterality, tuberculous mastitis is generally unilateral without a preferential side [4]. In the study by Emma McGuire et al. [13], by Hawilo A. et al. [10] the involvement is unilateral in all cases.

Breast lesions due to tuberculosis have nonspecific ultrasonography features [3] [6]. The definitive diagnosis is bacteriological and is based on Mycobacterium tuberculosis discovery in the fluid sample or in an abscess sample. However, this eventuality is rare and Mycobacterium tuberculosis is only found in 25\% of cases [3] [7]. Emma McGuire et al. note that the sensitivity of breast tissue is low (3.8\% and 19.5\%) [13]. Surgery excision for histological examination is essential for the diagnosis [3] [12].

On histological examination, granulomatous necrotic inflammation is a characteristic of tuberculosis infection. It is necessary to eliminate differential diagnosis such as infectious and non-infectious breast pathologies [13]. The diagnosis is confirmed by the classic appearance of epithelioid granuloma with caseous necrosis [3]. In $95 \%$ of cases, there were epithelioid granulomas with central caseous necrosis and multinucleated giant cells. This characteristic feature helps to make the differential diagnosis with breast cancer [3] [11]. In the study by H. Zekri et al. [3], caseous necrosis is essential criteria for diagnosis of breast tuberculosis, and all epithelioid granulomatous and multinucleated giant cells without caseous necrosis are considered to be granulomatous mastitis. Jorge Isaac Sánchez-Miño et al. [14] reported a case with clinical and nonspecific im- 
aging features in which a malignant lesion was suspected. However, histological examination showed giant cells, caseous necrosis and granulomatous lesions, which confirm the diagnosis of tuberculosis.

In our case, regarding the patient's age, the clinical appearance of the lesion and the ultrasonography data (lesion classified ACR4), carcinomatous mastitis was the first diagnosis suspected. This led to perform a surgical excision. But histological examination confirmed the diagnosis of breast tuberculosis.

It is important to distinguish the type of breast tuberculosis. According to the contamination, there are 2 forms, primary and secondary breast tuberculosis. The primary form is due to contamination by direct inoculation of Koch's bacillus through the milk ducts or through a skin lesion. It is likely favored by breastfeeding and pregnancy. It is the most form [15] and represents $62.5 \%$ of cases (5/8 cases) in the series of Hawilo A et al. [10] and $90 \%$ of cases in that of $\mathrm{H}$. Zekri et al. [3]. It is secondary breast tuberculosis when the breast tissue is contaminated either by hematogenous or lymphatic dissemination. This form represents $10 \%$ of cases in the study of H. Zekri et al. [3], 37.5\% in Hawilo A. et al. serie [10]. Our case was probably primary due to the absence of other tuberculous localization.

\section{Conclusion}

Breast tuberculosis is rare. Breast tissue is an exceptional localization of tuberculosis. The diagnosis is sometimes difficult due to non-specific clinical and radiological features. The diagnosis is based on bacteriological examination, but it is less sensitive. In the absence of bacteriological confirmation, histological examination is essential to confirm the diagnosis and to make the differential diagnosis with other lesions, especially breast cancer.

\section{Conflicts of Interest}

The authors declare no conflicts of interest regarding the publication of this paper.

\section{References}

[1] Ben Hassouna, J., Gamoudi, A., Bouzaïene, H., et al. (2005) Tuberculose mammaire: Étude rétrospective de 65 cas. Gynécologie Obstétrique et Fertilité, 33, 870-876. https://doi.org/10.1016/j.gyobfe.2005.08.020

[2] Kilic, M.O., Saglam, C., Agca, F.D. and Terzioglu, S.G. (2016) Clinical, Diagnostic and Therapeutic Management of Patients with Breast Tuberculosis: Analysis of 46 Cases. Kaohsing Journal of Médical Sciences, 32, 27-31. https://doi.org/10.1016/j.kjms.2015.12.005

[3] Zekri, H., Boufettal, H., Bennani, O., Laghzaoui, M. and Bouhya, S. (2010) La tuberculose mammaire à propos de 10 cas. Journal Marocain des Sciences Médicales, 2, 19-23.

[4] Strazzanti, A., Trovato, C., Gangi, S. and Basile, F. (2018) Breast Tuberculosis Cases Rising in Sicily. International Journal of Surgery Case Reports, 53, 9-12. 
https://doi.org/10.1016/j.ijscr.2018.09.048

[5] Roy, P.M., Cornu, P., Lebas, F., et al. (1996) Une cause rare de tuméfaction pseudonéoplasique du sein: La tuberculose mammaire. La Revue de Médecine Interne, 17, 173-175. https://doi.org/10.1016/0248-8663(96)82972-9

[6] Shrestha, A., Gautam, K., Pyakurel, D., Pradhan, S. and Pant, V. (2019) Breast Tuberculosis, a Rare Entity. IDCases, 15, e00530. https://doi.org/10.1016/j.idcr.2019.e00530

[7] Rajaonarison J.J.C., Rakotondraisoa, J.M., Rasoanandrianina, B.S., Ravelosoa, E. and Randriambololona, D.M.A. (2015) Un nouveau cas de tuberculose primitive mammaire. La Revue Médicale de Madagascar, 5, 534-537.

[8] Mehta, G., Mittal, A. and Verma, S. (2010) Breast Tuberculosis Clinical Spectrum and Management. Indian Journal of Surgery, 72, 433-437. https://doi.org/10.1007/s12262-010-0166-5

[9] Shinde, S.R., Chandawarkar, R.Y. and Deshmukh, S.P. (1995) Tuberculosis of the Breast Masquerading as Carcinoma: A Study of 100 Patients. World Journal of Surgery, 19, 379-381. https://doi.org/10.1007/BF00299163

[10] Hawilo, A., Abdelmalek, R., Mebazaa, A., Addouni, O., Kanoun, F., El Euch, D., Haouet, S., Zitouna, M., Mokni, M., Ben Osman, A. and Ben Chaabane, T. (2012) La tuberculose mammaire: Un diagnostic rare, souvent méconnu. Medecine et Sante Tropicales, 22, 292-296. https://doi.org/10.1684/mst.2012.0081

[11] Rakoto-Ratsimba, H.N., Samison, L.H., Razafimahandry, H.J.C., Rakototiana, A.F., Imbiki, Z. and Ranaivozanany, A. (2005) Deux observations de tuberculose mammaire à Madagascar. Médecine Tropicale, 65, 355-358.

[12] Hafidi, M.R., Kouach, J., Hamidi, L.A., Achenani, M., Benchakroun, K., Salek, G., et al. (2011) Tuberculose mammaire à propos de deux cas. Mali Medical, 2, 58-61.

[13] McGuire, E., Carey, L., Tiberi, S., Rahman, A., Jayasekera, N., White, V. and Kunst, H. (2019) Breast Tuberculosis in East London: A 13-Year Retrospective Observational Study. The Breast Journal, 26, 235-239. https://doi.org/10.1111/tbj.13517

[14] Sánchez-Miño, J.I., Rodríguez, A.M.O., Orozco, L.G., Mera, B.V., Yepez-Yerovi, F.E. and Escalona-Rabaza, M. (2018) Tuberculosis de mama: Reporte de un caso. Revista Peruana de Medicina Experimental y Salud Publica, 35, 333-337. https://doi.org/10.17843/rpmesp.2018.352.3131

[15] Bouhout, T., Serji, B., Egyir, E.U., El amri, B., Bouhout, I., Soufi, M., Bouziane, M. and El harroudi, T. (2017) Tuberculose mammaire: À propos d'un cas. Pan African Medical Journal, 28, 183. https://doi.org/10.11604/pamj.2017.28.183.10742 